ISSN 1392-3196 / e-ISSN 2335-8947

Zemdirbyste-Agriculture, vol. 100, No. 3 (2013), p. 293-302

DOI $10.13080 / \mathrm{z}-\mathrm{a} .2013 .100 .038$

\title{
Species diversity of weevils (Ceutorhynchus spp.), migration activity and damage in winter and spring oilseed rape
}

\author{
Birutė VAITELYTĖ, Irena BRAZAUSKIENĖ, Eglè PETRAITIENĖ \\ Institute of Agriculture, Lithuanian Research Centre for Agriculture and Forestry \\ Instituto 1, Akademija, Kèdainiai distr., Lithuania \\ E-mail: birute.vaitelyte@1zi.lt
}

\begin{abstract}
Species diversity of weevils (Ceutorhynchus) and their migration activity in winter and spring rape crops were studied at the Institute of Agriculture, Lithuanian Research Centre for Agriculture and Forestry during 2010-2012. Yellow water traps were used for collecting adults of Ceutorhynchus species and their oviposition and larvae development were evaluated on the petioles, stems and pods of winter and spring rape plants. The abundance of weevils (Ceutorhynchus spp.) was much higher in the winter rape crop in comparison with spring rape. The following three species prevailed in winter and spring rape: Ceutorhynchus pallidactylus, C. typhae and $C$. obstrictus. The flying activity of $C$. pallidactylus in the winter rape crop annually started at growth stage (GS) 39 and lasted for 4-5 weeks; however, in the spring rape crop - at GS 9 and lasted for only 1-2 weeks. Oviposition of $C$. pallidactylus lasted for 2-4 weeks in both crops. The peak amount of $C$. pallidactylus larvae was recorded at GS 65-67 in winter and at GS 57-61 in spring rape crop. Larvae in petioles and stems in winter and spring rape were detected for 5-6 weeks. A high abundance of C. obstrictus adults in winter rape was recorded at GS 65-73; however, migration of this insect to the spring rape crop was week during all experimental period. In the winter rape crop, oviposition of $C$. obstrictus lasted for 2-3 weeks and in spring rape for 1-2 weeks. The largest number of C. obstrictus larvae was determined at GS 73-79 in winter rape, at GS 67-75 in spring rape. Strong and significant $\left(p=0.05^{*}, p=0.01^{* *}\right)$ correlations were established between the abundance of $C$. pallidactylus larvae/plant and percent of damaged stems $\left(r=0.909^{* *}\right)$, also between abundance of $C$. pallidactylus larvae/plant and damaged stem length $\left(r=0.931^{* *}\right)$. C. obstrictus larvae abundance in the pods also highly and significantly correlated with the percentage of damaged pods and seeds $\left(r=0.874^{*}, r=0.931^{* *}\right.$, respectively).
\end{abstract}

Key words: Brassica napus, Ceutorhynchus obstrictus, Ceutorhynchus pallidactylus.

\section{Introduction}

Oilseed rape (Brassica napus L.) is most important in food industry, bio-fuel industry and as a rotation plant in many countries. In Lithuania, oilseed rape is currently one of the most promising crops. The area of oilseed rape is increasing from year to year. According to Statistics Lithuania, at the end of 2002 oilseed rape was cultivated on 60000 ha and in 2012 the area increased up to 262700 ha. The damage of pests is one of the major factors limiting seed yield of oilseed rape. Some of Ceutorhynchus species can be mentioned as especially harmful to crucifers, as their imago and larvae target specific plant parts (Alford et al., 2003).

Weevils are the primal pest in oilseed rape crops in many countries (Dosdall et al., 2001; Alford et al., 2003, Toshova et al., 2009). In the Czech Republic, the dominant pests of winter and spring oilseed rape are Ceutorhynchus pallidactylus (syn. C. quadridens), C. obstrictus (syn. C.assimilis), and C. napi (Sedivy, Vasak, 2002). In Hungary, the greatest damage was caused by $C$. pallidactylus and C. obstrictus (Marczali et al., 2010). The most abundant species was C. typhae (syn. C. floralis) in Bulgaria; however, C. pallidactylus, C. obstrictus, C. napi, C. erysimi and C. picitarsis were found in low numbers on Brassicaceae crops (Toshova et al., 2009). $C$. obstrictus, C. rapae, C. pleurostigma and C. typhae species were distributed on oilseed rape crops in Estonia (Tarnag etal., 2004). Four species (C. pallidactylus, C. picitarsis, $C$. sulcicollis and C. typhae) of weevils were identified in oilseed rape crops in Latvia (Grantina et al., $2011 \mathrm{a} ; \mathrm{b})$.

In early spring, adults of $C$. pallidactylus migrate to oilseed rape fields. Cabbage stem weevil females deposit their eggs into petioles and young leaves. Larvae of weevils feed inside petioles and later invade inside stems (Williams, 2010). C. obstrictus adults usually attack oilseed rape during the flowering and are more feeding on winter oilseed rape plants (Ferguson et al., 2000; Williams, 2010). Adults feeding on inflorescence emergence stage cause buds to desiccate and racemes to bear fewer pods, by larval feeding on seeds within pods, and by premature shattering of infected pods (Dosdall et al., 2001). Both species are limiting factors for oilseed rape production. Oilseed rape seed yield losses caused by $C$. pallidactylus larvae were recorded up to $50 \%$ in the United Kingdom (Alford et al., 2003; Dechert, Ulber, 2004) and up to $20 \%$ in Germany (Lanschreiber, 2005). 
Cabbage seed weevil larvae damage can reduce yield up to $18 \%$ (Williams, Free, 1979).

Management of pests in commercial crops of winter and spring oilseed rape in Europe still relies on insecticides, most often applied routinely, often without regard to pest incidence (Williams, 2010). The migration of weevil's adults and the time of their arrival on oilseed rape crops are of particular importance for related seed yield losses. Determination of weevil migration, especially the time of their migration into crops, seems to be limiting factors to their population development and risk of exceeding a threshold. Future pest management strategies are focussed on understanding of the spatial temporal interactions of the pests (Williams et al., 2003; Williams, 2010). This would help more efficient targeting of insecticides application and reduce pesticides use (Murchei et al., 1997).

InLithuania, little is known about the harmfulness of stem and pod pests in oilseed rape. It was published earlier that Ceutorhynchus species do not have economic importance in oilseed rape crops in Lithuania (Tamutis, 2002). During the last decade the area of oilseed rape has increased and higher invasion of Ceutorhynchus species to the winter and spring rape fields is expected. The aim of our research was: 1) to investigate the abundance of weevil's (Ceutorhynchus spp.) adults in winter and spring rape, 2) to identify their species, 3 ) to estimate the time of arrival of $C$. pallidactylus and C. obstrictus adults into winter and spring rape fields, their flight activity period, oviposition, larvae development and damage.

\section{Materials and methods}

The experiments were performed at the Institute of Agriculture, Lithuanian Research Centre for Agriculture and Forestry, during 2010-2012 in the winter (cv. 'Sunday') and spring (cv. 'Landmark') oilseed rape crops. The crops were grown following the approved conventional growing technologies for oilseed rape. Experimental plots $50 \times 100$ $\mathrm{m}$ in size were set up in winter and spring rape fields over all three experimental years. No pest control products were applied in those plots.

Yellow water traps (YWT) (Moerickes dishes) were used for the collection of adults of Ceutorhynchus species. YWT were set 2, 5, 10, 20, and 45 meters (4 traps per place) away from the edge of winter and spring oilseed rape fields. YWT $(26 \times 26 \mathrm{~cm})$ were filled to one third of their volume with water and $0.01 \%$ washing liquid was added to break the surface tension and to drown the insects. Insect traps were emptied each week, on the same day of the week, at 9 a.m., before pests started day flight activity. The beetles collected were preserved in screwtop bottles, filled with $70 \%$ ethyl alcohol until required. Weevils in winter rape field were collected from the beginning of vegetation in spring until harvesting and in spring rape field - from emergence until harvesting. In the laboratory Ceutorhynchus weevils were selected from other insects, analysed and Ceutorhynchus species were identified by using pest descriptors and identification keys (Smreczynski, 1972; Alford et al., 2003). Ceutorhynchus species systematics were used following the latest catalogue of Lithuanian beetles (Tamutis et al., 2011). C. pallidactylus oviposition and larvae development were investigated in winter and spring rape during the vegetation period. Every week, one hundred of stems was analysed, 10 stems per place from 10 marked places per field. Stems and leaf petioles estimated in the laboratory were cut lengthwise; eggs and larvae of C. pallidactylus were counted. Plant height and length of larvae-damaged stem were measured. Oviposition of C. obstrictus and larvae development on the pods was started to evaluate from the middle of flowering stage (GS 65) until harvesting. One hundred pods, from 5 marked places, 10 pods from the main inflorescence and 10 pods from side racemes were randomly sampled. In the laboratory, the pods were opened and analysed, eggs and larvae of C. obstrictus were identified and counted. At the same time healthy and damaged seeds in the pods were identified.

Plant growth stages were assessed according to growth stages (GS) scale (Lancashire et al., 1991). Main meteorological data were taken from the Dotnuva Meteorological Station located approximately $1 \mathrm{~km}$ from the experimental plots. The sum of active temperatures was defined as the sum of daily mean temperatures exceeding $5^{\circ} \mathrm{C}$. Below that threshold the temperature was not considered effective. The active temperature sum was recorded on each day after 1 January when the daily average temperature reached $5^{\circ} \mathrm{C}$.

The data were subjected to analysis of variance ANOVA. Standard error ( \pm SE) for all data was calculated using routine statistical methods. The correlations between pest damage and larvae abundance were calculated (Clever, Scarisbrick, 2001). Software package STATISTICA version 5.5 was used for statistical analysis.

\section{Results and discussion}

Species diversity. During the experimental period a total number of 8767 weevils in the yellow water traps (YWT) from winter rape and 827 weevils from spring rape fields were collected. It shows that the abundance of Ceutorhynchus spp. was much higher in winter rape field in comparison with spring rape. After analysis, six Ceutorhynchus species were identified in the samples from winter and spring rape (Table). One of the most numerous species in winter rape in 2010 was identified C. typhae (50.2\%); however, during 2011 and 2012 the prevailing species was C. pallidactylus $(64.0 \%$ and $54.8 \%$, respectively).

Spring rape was also frequently visited by C. typhae; however, this species usually is not damaging oilseed rape and feeds mainly on seeds of non-cultivated wild cruciferous species, particularly on Capsella bursapastoris (Kuhlmann, Mason, 2002; Kuhlmann et al., 2006). Only C. pallidactylus and C. obstrictus are known widely as damaging oil seed rape (Alford et al., 2003; Williams, 2010). The abundance of $C$. pallidactylus in spring rape during experimental period was much lower in comparison with winter rape; however, its abundance amounted to $12.3-53.2 \%$ of the total number of weevils in the annual samples from spring rape field. Our results agree with previous reports that $C$. pallidactylus is a major pest attacking oilseed rape (Alford et al., 2003; Grantina et al., 2011 b). During experimental period in winter and spring rape $C$. obstrictus was identified as very numerous species; however, its abundance was lower in comparison with $C$. pallidactylus (Table). Other species identified from winter and spring rape were $C$. erysimi, C. rapae, and C. sulcicollis. 
Table. The diversity of Ceutorhynchus species in winter and spring oilseed rape

\begin{tabular}{|c|c|c|c|c|c|c|}
\hline \multirow{2}{*}{ Species } & \multicolumn{2}{|c|}{2010} & \multicolumn{2}{|c|}{2011} & \multicolumn{2}{|c|}{2012} \\
\hline & number & $\%$ from total & number & $\%$ from total & number & $\%$ from total \\
\hline & \multicolumn{6}{|c|}{ Winter oilseed rape } \\
\hline C. erysimi (Fabricius, 1787) & 20 & 0.6 & 97 & 2.4 & 9 & 0.6 \\
\hline C. obstrictus (Marsham, 1802) & 433 & 13.7 & 644 & 16.2 & 376 & 23.1 \\
\hline C. pallidactylus (Marsham, 1802) & 1088 & 34.3 & 2539 & 64.0 & 894 & 54.8 \\
\hline C. rapae (Gyllenhal, 1837) & 12 & 0.4 & 27 & 0.7 & 23 & 1.4 \\
\hline C. sulcicollis (Paykull, 1800) & 25 & 0.8 & 80 & 2.0 & 12 & 0.7 \\
\hline C. typhae (Herbst, 1795) & 1590 & 50.2 & 582 & 14.7 & 316 & 19.4 \\
\hline \multirow[t]{2}{*}{ Total } & 3168 & & 3969 & & 1630 & \\
\hline & \multicolumn{6}{|c|}{ Spring oilseed rape } \\
\hline C. erysimi (Fabricius, 1787) & 1 & 0.5 & 0 & 0.0 & 2 & 0.5 \\
\hline C. obstrictus (Marsham, 1802) & 40 & 19.4 & 25 & 14.0 & 65 & 14.7 \\
\hline C. pallidactylus (Marsham, 1802) & 62 & 30.1 & 22 & 12.3 & 235 & 53.2 \\
\hline C. rapae (Gyllenhal, 1837) & 1 & 0.5 & 14 & 7.8 & 27 & 6.1 \\
\hline C. sulcicollis (Paykull, 1800) & 5 & 2.4 & 0 & 0.0 & 5 & 1.2 \\
\hline C. typhae (Herbst, 1795) & 97 & 47.1 & 118 & 65.9 & 108 & 24.3 \\
\hline Total & 206 & & 179 & & 442 & \\
\hline
\end{tabular}

Migration activity, oviposition and larvae development of Ceutorhynchus pallidactylus. The date when the first specimens of $C$. pallidactylus in the YWT from winter rape field were observed was variable during experimental period; however, the major flight activity of $C$. pallidactylus to winter rape annually started at the same time - at GS 39, in the second ten day period of April (Fig. 1). The sum of active temperatures $\left(>5^{\circ} \mathrm{C}\right)$ at that time in 2010 and 2011 seasons reached 47.6 and $52.7^{\circ} \mathrm{C}$, average weekly air temperature rose to $6.7^{\circ} \mathrm{C}$ and $6.9^{\circ} \mathrm{C}$, respectively. During 2012 , active migration of $C$. pallidactylus started when the average weekly air temperature rose to $7.2^{\circ} \mathrm{C}$, notwithstanding the sum of active temperatures was much lower $-21.5^{\circ} \mathrm{C}$. According to Grantina et al. $(2011 \mathrm{a} ; \mathrm{b})$ the first catches of $C$. pallidactylus in Latvia were registered when the air temperature exceeded $6^{\circ} \mathrm{C}$ and the sum of accumulated active temperatures reached $86^{\circ} \mathrm{C}$. Major activity of C. pallidactylus adults in winter rape lasted for 4-5 weeks (from 14-21 April till 15-19 May) and their highest abundance was estimated during 20-26 of April 2011 (136.8 \pm 8.31 specimens); however, the spread of this insect during 2010 and 2012 seasons was much lower: the highest number of adults caught during one week in one YWT was $38.8 \pm 2.42$ specimens during 22-28 of April 2010 and $32.8 \pm 2.11$ specimens during 25 April-1 May 2012 (Fig. 1). In later observation periods only few $C$. pallidactylus adults per week were estimated in YWT; however, their abundance increased on the first ten day period of July, at the ripening stage (GS 83-85) of winter rape. It seems that the reason was new generation of $C$. pallidactylus adults. New generation of $C$. pallidactylus weevils has been identified in Latvia also (Grantina et al., 2011 b). The migration of C. pallidactylus to the spring oilseed rape field started at the end of April, one week after sowing, at germination stage and one-two weeks later, at the beginning of leaf development stage the peak of abundance was reached (Fig. 1). Flight activity of this insect in spring rape was much lower and shorter in comparison with winter rape. The highest abundance of weevils of $C$. pallidactylus during major flying activity in spring rape was observed in 2012 and reached $15.1 \pm 0.89$ specimens per week/ per YWT. However, major activity of $C$. pallidactylus adults in spring rape lasted for only one-two weeks. The differences in flight activity may be due to the differences in the growth habit of winter and spring oilseed rape. Spring oilseed rape has short ground rosette phenophase and fast stem elongation and such plants are unsuitable for the oviposition of $C$. pallidactylus adults that lay eggs in leaves of oilseed rape plants (Sedivy, Vasak, 2002).

During the experimental period, C. pallidactylus adults were found in winter and spring oilseed rape in the traps placed 2-45 meters from the field edge (Fig. 2). No significant differences were obtained in the amount of weevils caught at different distances from the field edge.

The first eggs of $C$. pallidactylus in the petioles of winter and spring rape during 2010 season were spotted at inflorescence emergence stage (GS 57 and 53, respectively); however, during 2011 and 2012 first eggs in winter rape were observed at GS 39 and in spring rape - at GS 32 (Fig. 3). During the experimental period the number of $C$. pallidactylus eggs/plant observed was much higher in winter rape compared with spring rape. During 2010-2012, the peak number of eggs in winter rape was recorded at GS 57-61 and at GS 52-57 in spring rape. The highest number of eggs was recorded in 2011 in winter rape (11.1 eggs per plant); however, in spring rape the highest number of eggs was recorded during the same season and amounted to 1.9 eggs per plant. Eggs in winter rape petioles were observed for $2-3$ weeks and in spring rape for 2-4 weeks.

At GS 57-61, the first $C$. pallidactylus larvae started hatching in winter and spring rape petioles (Fig. 3), and later, at GS 65, the larvae started to migrate from the petioles into stems. During experimental period the peak number of $C$. pallidactylus larvae was recorded at GS 65-67 in winter rape and at GS 57-61 in spring rape. The highest number of larvae recorded in winter rape reached 10.3 per plant during 2011 growing season; however, the highest number of larvae in spring rape did not exceed 1.6 per plant (in 2010). Larvae were observed in the stems of winter and spring rape for 5-6 weeks and at the end of flowering-beginning of pod development stage (GS 69-70) a sudden larvae migration to the soil and transition from larvae to pupae started. After hatching in summer, adults of new generation feed on the leaves of other species of the Brassicaceae family before hibernation (Alford et al., 2003; Moser et al., 2009). 

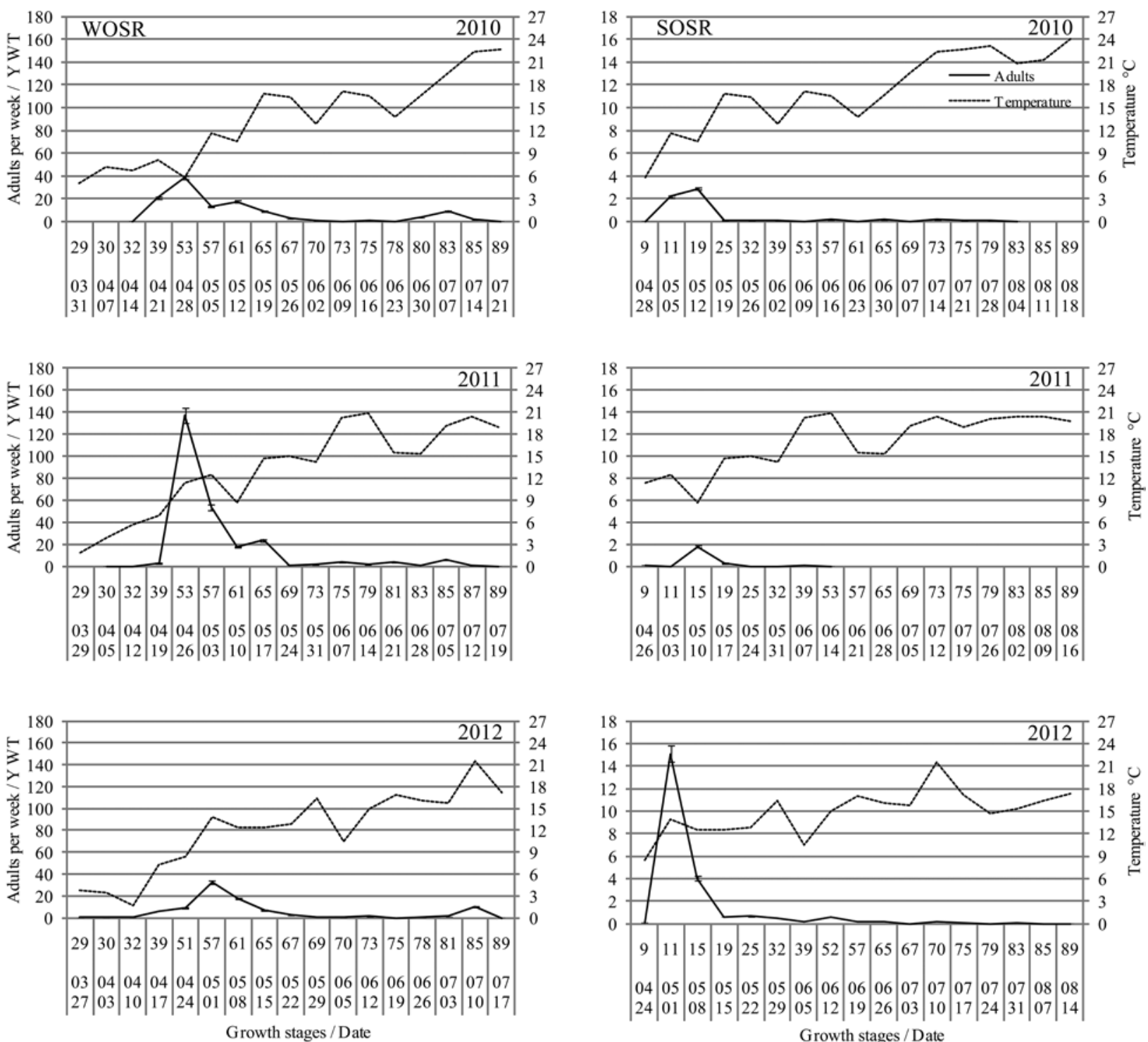

YWT - yellow water traps

Figure 1. Migration activity of Ceutorhynchus pallidactylus adults (amount $\pm \mathrm{SE}$ ) in winter (WOSR) and spring oilseed rape (SOSR) and average weekly air temperature during 2010-2012 growing seasons

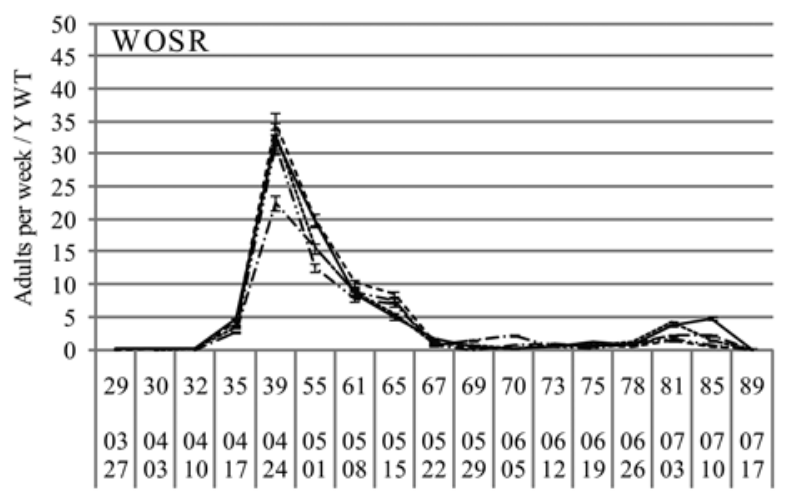

Growth stages / Date

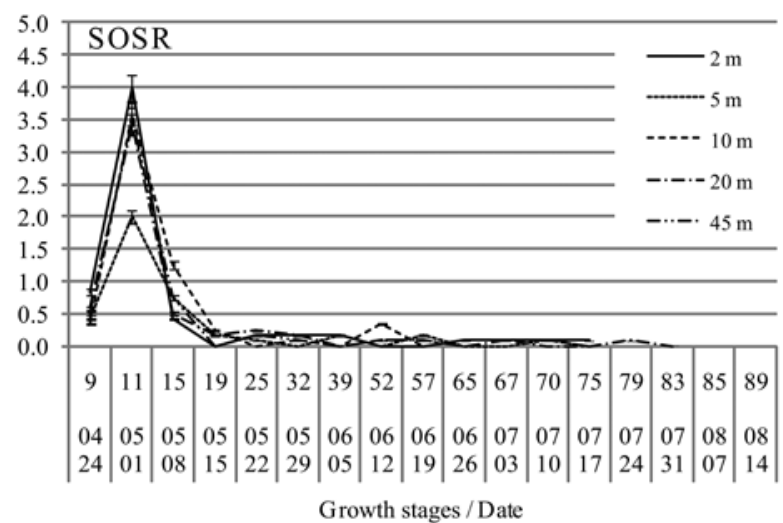

YWT - yellow water traps

Figure 2. Ceutorhynchus pallidactylus migration (amount $\pm \mathrm{SE}$ ) in winter (WOSR) and spring oilseed rape (SOSR) field depending on the distance from the edge of the field (averaged data over 2010-2012) 

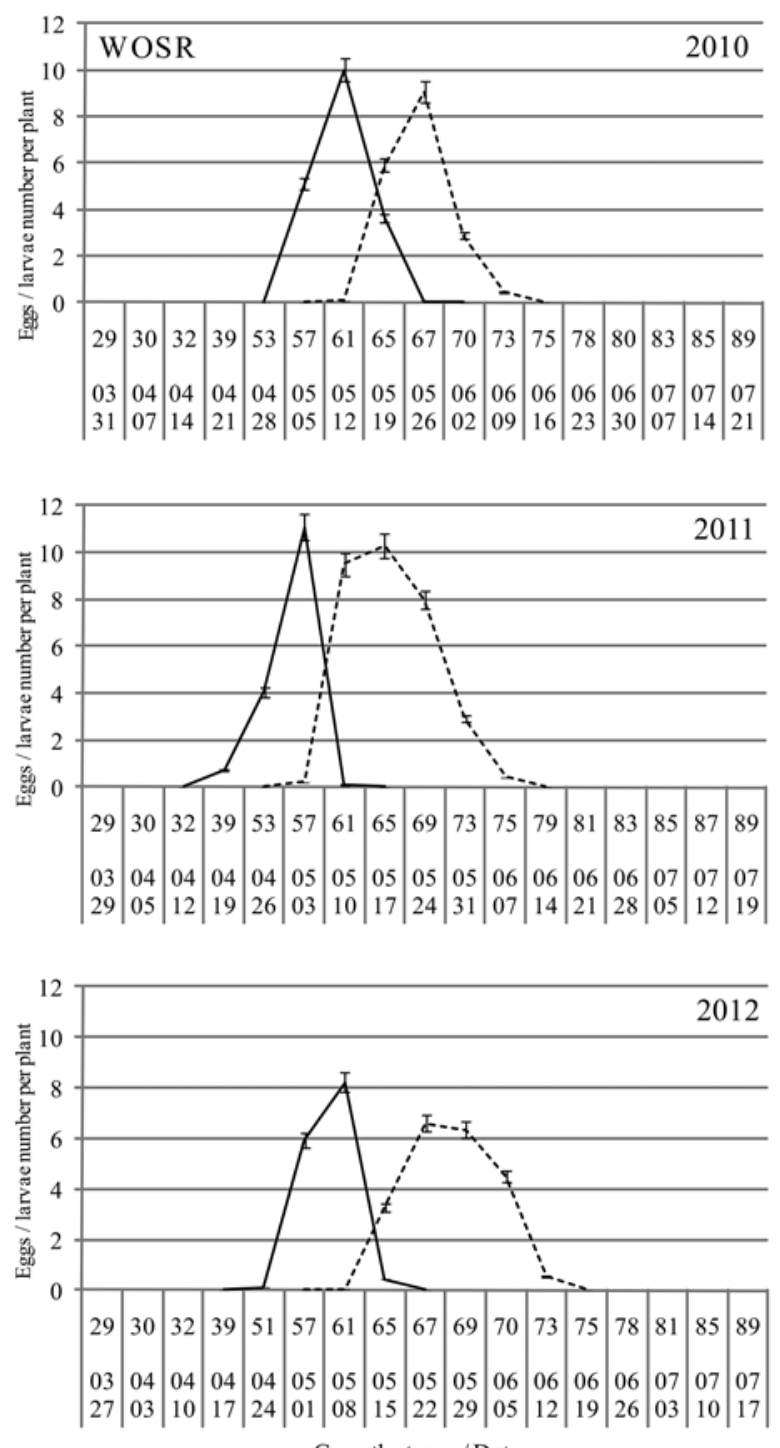

Growth stages / Date
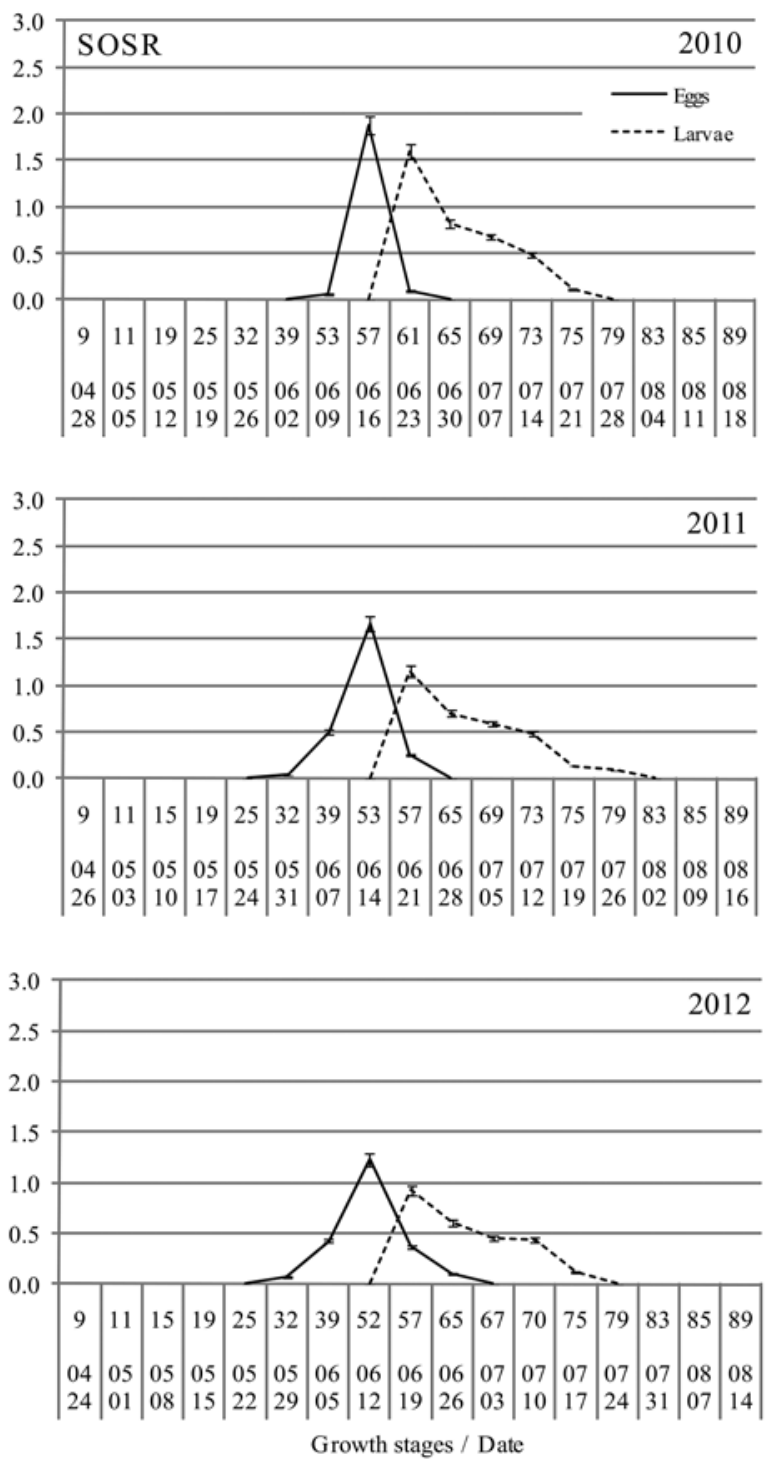

Figure 3. Oviposition of Ceutorhynchus pallidactylus and larvae development (amount $\pm \mathrm{SE}$ ) in winter (WOSR) and spring oilseed rape (SOSR) during 2010-2012 growing seasons

Migration activity, oviposition and larvae development of Ceutorhynchus obstrictus. During experimental period, invasion of $C$. obstrictus adults to the winter rape field started at the middle of inflorescence emergence stage and reached maximum numbers at full of flowering till the beginning of pod development stage (GS 65-73) (Fig. 4). Average weekly air temperature at that time reached $10.5-14.6^{\circ} \mathrm{C}$. It is supported by earlier report that $C$. obstrictus end their hibernation and fly to cruciferous plants in the spring when the air temperature exceeds $15^{\circ} \mathrm{C}$ (Ulmer, Dosdall, 2006). Two peaks of $C$.obstrictus invasion to the winter rape field were recorded in 2010 and 2012 and another peak was observed in 2011. The highest number of specimens of C. obstrictus per week per YWT was recorded in 2011 during 24-31 May (17.4 \pm 1.25 specimens). Some adults of cabbage seed weevil were identified in winter rape field till the end of ripening stage (GS 89). Migration of that insect to the spring rape field was weak during all experimental period. During the experimental period, in spring rape the incidence of $C$. obstrictus adults was from 5.8 to 25.8 times lower compared with winter rape (Table) and it is likely that winter rape was much more attractive to $C$. obstrictus in comparison with spring rape. In our country like in Czech Republic the frequency of C. obstrictus weevils was higher in winter rape than in spring rape (Sedivy, Vasak, 2002).

During the experimental period, C. obstrictus adults were found in winter and spring oilseed rape in the traps which placed 2-45 meters from the field edge (Fig. 5). Significantly highest number of weevils caught 2 meters from the field edge was obtained only in winter rape in 2011; however, in other cases no significant differences were obtained in the number of weevils caught at different distances from the field edge.

The first eggs of $C$. obstrictus were spotted in winter and spring rape pods at flowering stage (GS 6567). The highest number of eggs/pod was recorded one week later, at the end of flowering or at the beginning of pod development stage (GS 69-73), when pods were young and small (Fig. 6). It is known that females of C. obstrictus lay eggs, usually singly in pod through a hole bored in pod wall with the mouth part and developing young pods are preferred for oviposition (Hiiesaar et al., 2003). In average at the peak $0.6-0.7$ eggs in winter rape and $0.2-0.3$ eggs per assessed pod in spring rape were 

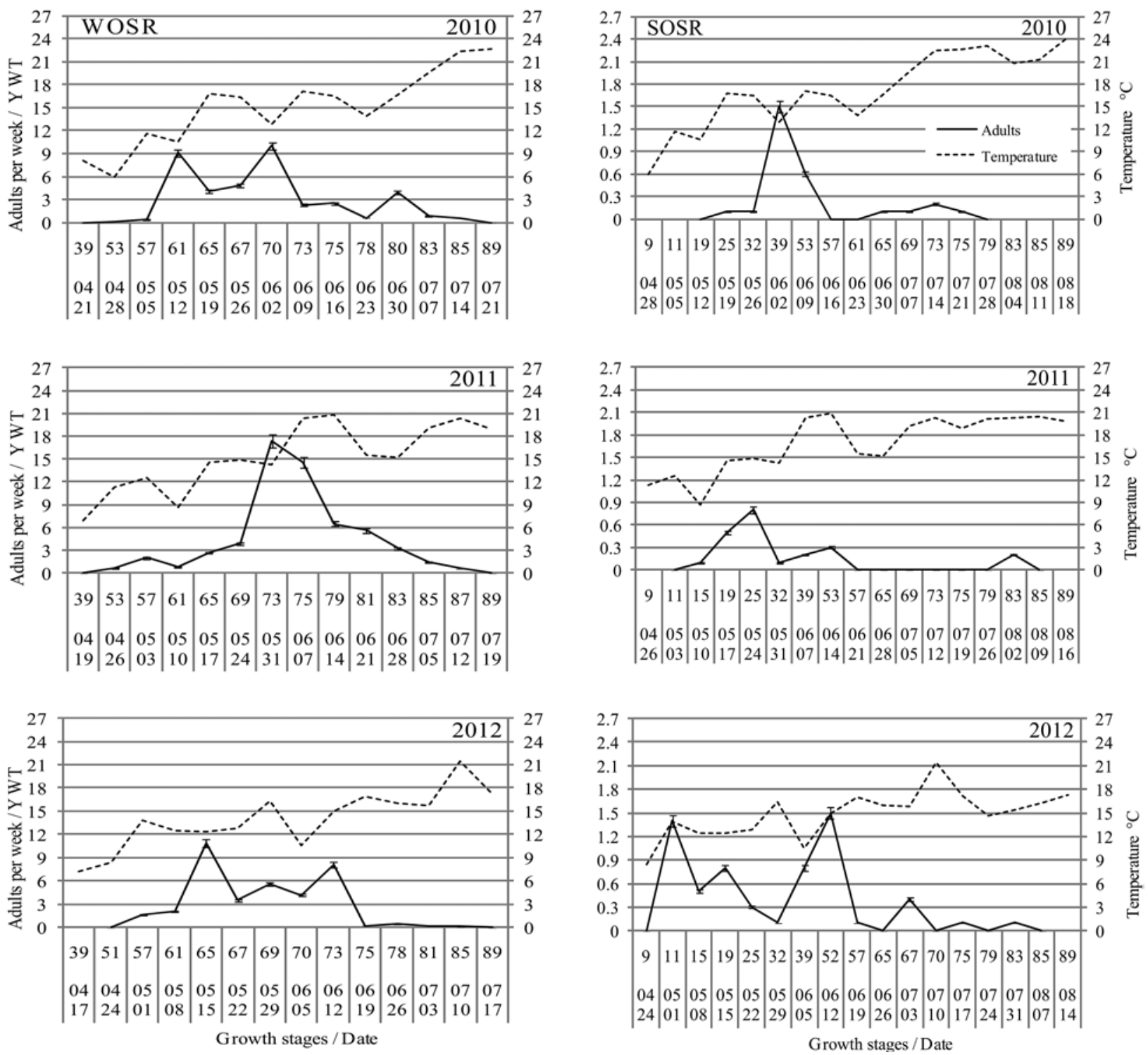

YWT - yellow water traps

Figure 4. Migration activity of Ceutorhynchus obstrictus adults (amount $\pm \mathrm{SE}$ ) in winter (WOSR) and spring oilseed rape (SOSR) and average weekly air temperature during 2010-2012 growing seasons
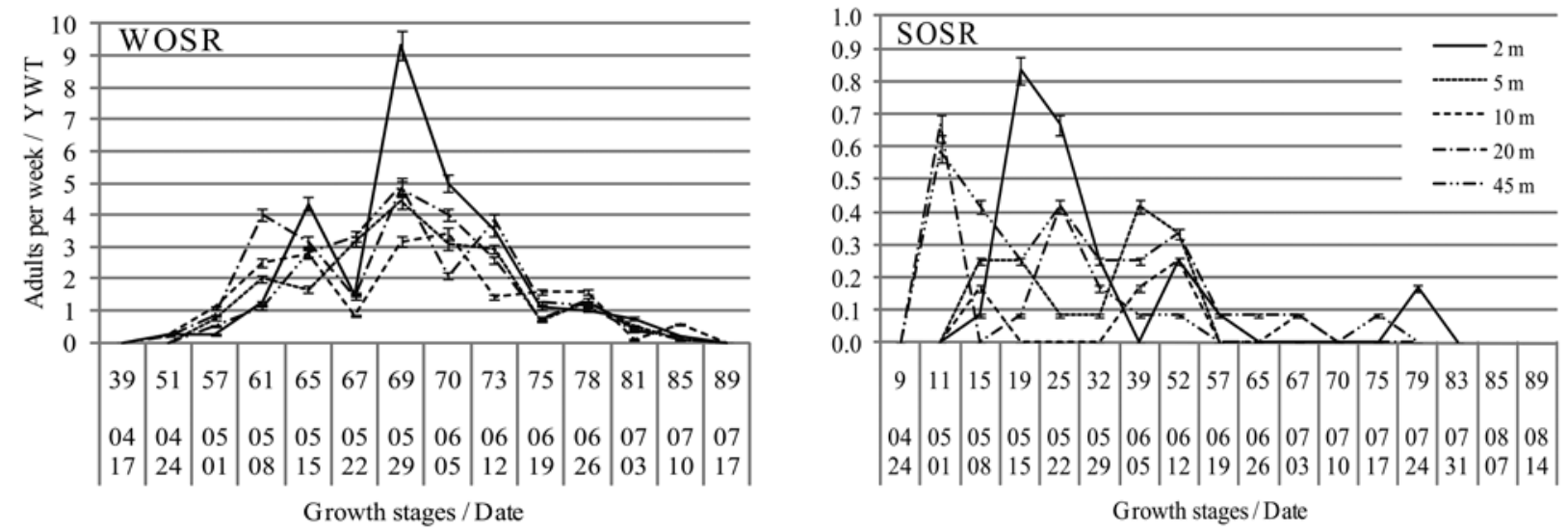

YWT - yellow water traps

Figure 5. Ceutorhynchus obstrictus migration (amount $\pm \mathrm{SE}$ ) in winter (WOSR) and spring oilseed rape (SOSR) field depending on the distance from the edge of the field (averaged data over 2010-2012) 

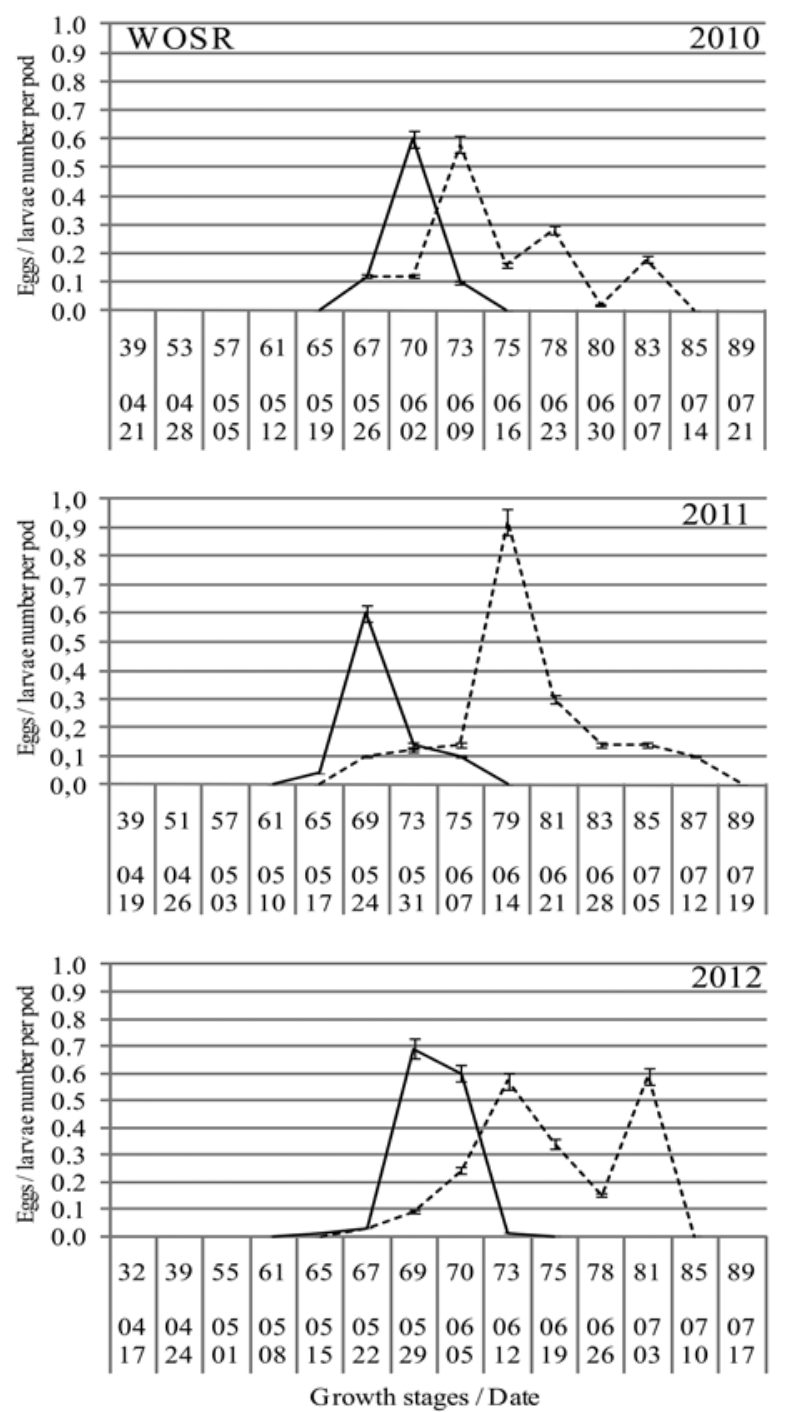
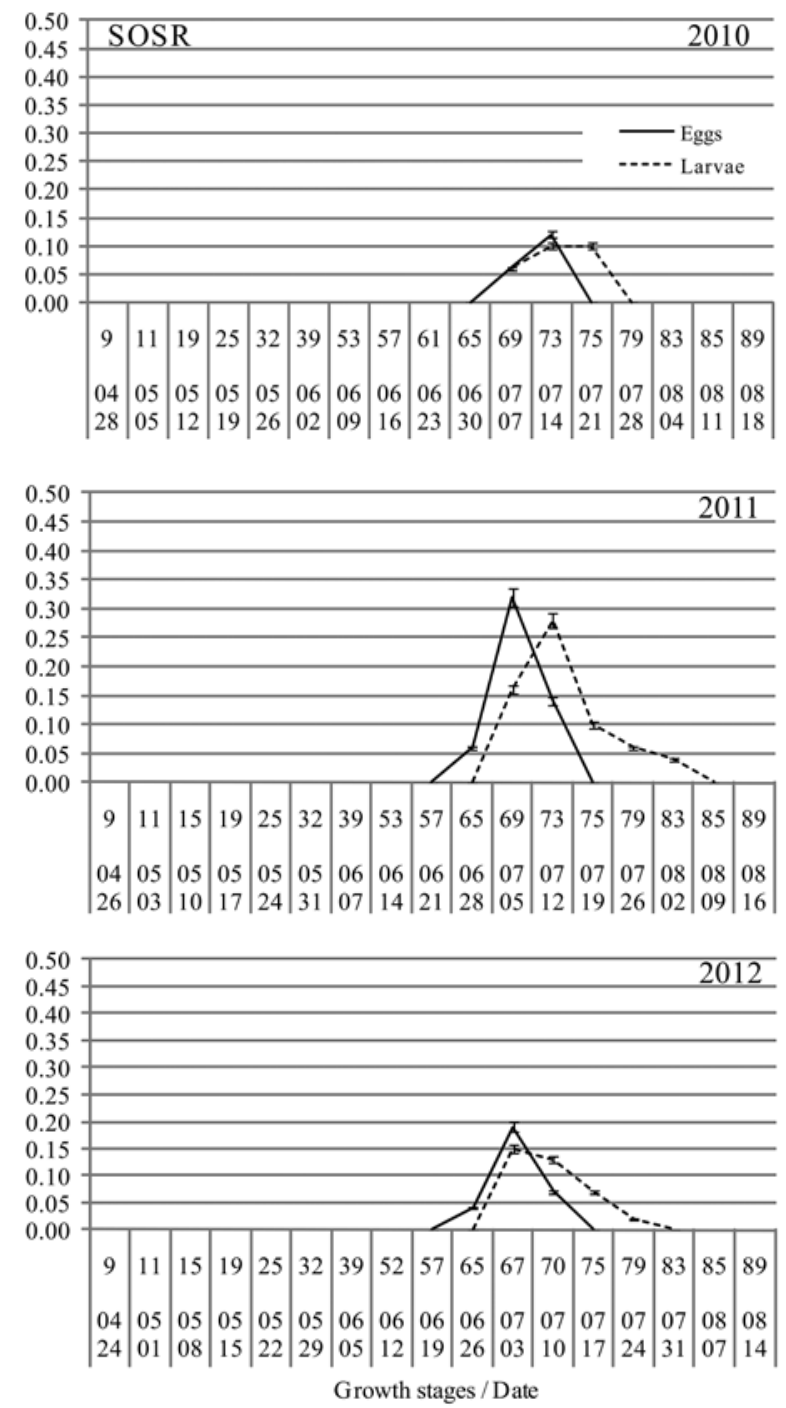

Figure 6. Oviposition of Ceutorhynchus obstrictus and larvae development (amount $\pm \mathrm{SE}$ ) in winter (WOSR) and spring oilseed rape (SOSR) during 2010-2012 growing seasons

observed. Oviposition lasted for 2-3 weeks in winter rape and 1-2 weeks in spring rape. The first $C$. obstrictus larvae started hatching in both winter and spring rape pods at the end of flowering (GS 67-69) and the peak was reached at GS 73-79 in winter rape, at GS 67-75 in spring rape. Infestation by $C$. obstrictus larvae was much higher and longer in winter rape compared with spring rape. The highest number of larvae per observed pod in winter rape reached 0.92 ; however, only 0.28 larvae per observed pod in spring rape (in both crops during 2011 season). Larvae infestation in winter rape lasted for 6-7 weeks; however, in spring rape for 2-4 weeks. In winter rape at ripening stage (GS 81-87), a sudden larvae migration to the soil and transition from larvae to pupae started. In spring rape larvae left pods earlier, at GS 75-83. C. obstrictus oviposition in winter rape usually lasted from the last ten-day period of May till the end of first ten-day period of June, larvae were found in the pods for a period 22-26 May - 03-12 July. Oviposition in spring rape pods lasted from the end of June till 10-14 July and infestation of pods by larvae was observed during whole July.

Damage. During the experimental period, C. pallidactylus larvae damaged all (100\%) observed stems of winter rape annually, and in spring rape damage was much lower - 22-42\% damaged stems (Fig. 7). Average damaged stem length in winter rape exceeded $62.3 \%$ and in spring rape $-14.6 \%$. Strong and significant $\left(P=0.05^{*}, P=0.01^{* *}\right)$ correlations were established between abundance of $C$. pallidactylus larvae/plant and percent of damaged stems $(r=0.909 * *)$, also between abundance of $C$. pallidactylus larvae/plant and damaged stem length $(r=0.931 * *)$. Our results showed that damage of cabbage stem weevil larvae was higher to winter than to spring rape and it is in disagreement with earlier reports (Williams, 2010). Other researchers have reported that cabbage stem weevil is a pest of both winter and spring rape throughout Europe (Bromand, 1990). High differences in the damage level between winter and spring rape crops in our country might be explained by different suitability of winter and spring rape plants for the development of $C$. pallidactylus (Sedivy, Vasak, 2002).

During the experimental period, cabbage seed weevil (C. obstrictus) larvae infested $5-7 \%$ of winter rape and $4-5 \%$ of spring rape pods (Fig. 8). It was observed that in average in winter rape larvae damaged $0.3-0.4 \%$ and in spring rape $-0.2 \%$ of seeds present in the pod. 


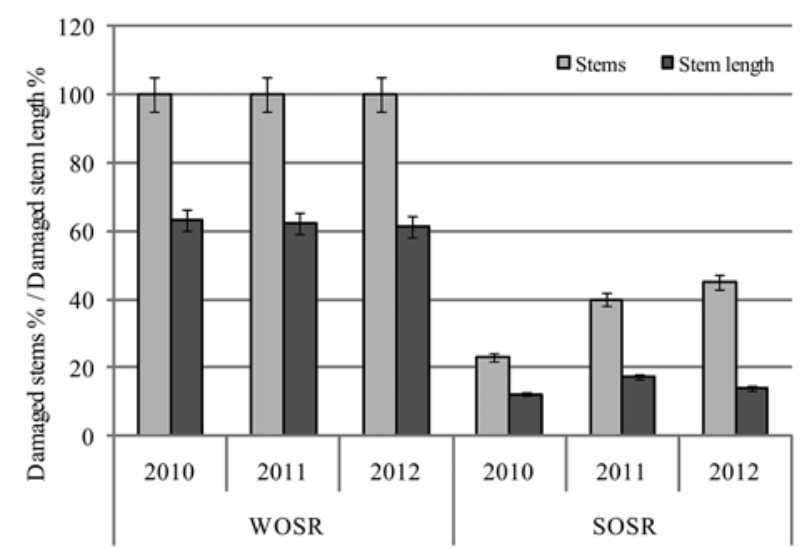

Figure 7. Damage of Ceutorhynchus pallidactylus larvae $(\% \pm \mathrm{SE})$ in winter (WOSR) (GS 73) and spring oilseed rape (SOSR) (GS 70-75) stems during 2010-2012

C. obstrictus larvae abundance in the pods highly and significantly correlated with the percentage of damaged pods and seeds ( $r=0.874^{*}, r=0.931^{* *}$, respectively). The cabbage seed weevil was more damaging to winter rape than to spring rape and our results are in agreement with those of other researchers (Free, Williams, 1979; Williams, 2010). However, damage in both crops was lower yield-limiting, which, according to Williams and Free (1979) is $8-15 \%$ of the seeds present in the pod. It was reported that the adults of cabbage seed weevil cause little direct damage to the crop but their feeding and egg-laying punctures in the pods may allow the brassica pod midge (Dasineura brassicae) to oviposit into them (Williams, 2010). Our results suggest that during experimental period cabbage seed weevil was not very important damaging pest in both winter and spring rape but further investigations are needed for estimating cabbage seed weevil role in the infestation of pods by brassica pod midge.

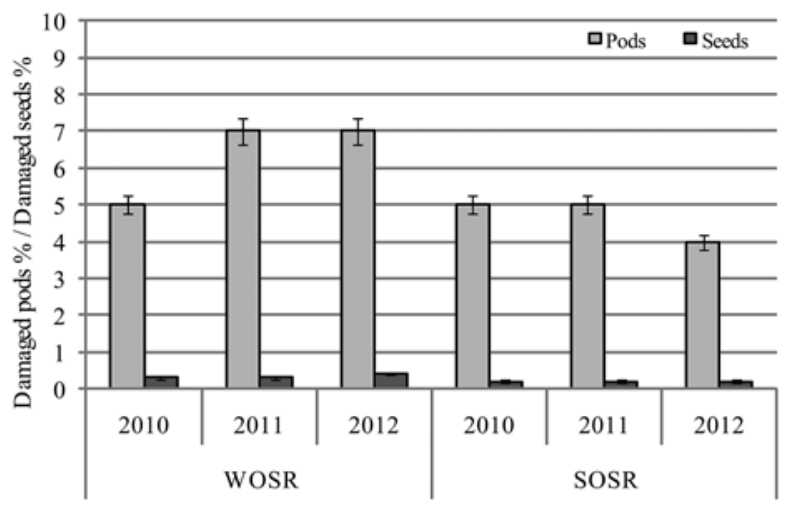

Figure 8. Damage of Ceutorhynchus obstrictus larvae (\% $\pm \mathrm{SE}$ ) in winter (WOSR) (GS 81-83) and spring oilseed rape (SOSR) (GS 75) pods during 2010-2012

\section{Conclusions}

1. The abundance of Ceutorhynchus specimens collected in YWT during the experimental period (2010-2012) was much higher from winter rape (8767 specimens) in comparison with spring rape field ( 827 specimens). In total six Ceutorhynchus species were identified in both crops: C. obstrictus, C. pallidactylus, C. typhae, C. erysimi, C. rapae and C. sulcicollis; however, the dominating species were $C$. pallidactylus, C. typhae and C. obstrictus.

2. The differences in flight activity of C. pallidactylus in winter rape and spring rape were estimated: in winter rape the abundance of weevils was much higher and flight activity longer in comparison with spring rape. The time of arrival of $C$. pallidactylus to winter rape was GS 39, to spring rape-GS 09. In both crops oviposition lasted for 2-4 weeks and larvae started hatching at GS 57-61.

3. Infestation of cabbage stem weevil larvae was much higher in winter rape (100\% damaged stems) compared with spring rape (22-42\% of stems). Strong and significant correlations were established between the abundance of $C$. pallidactylus larvae /plant and percentage of damaged stems.

4. During experimental period, the incidence of C. obstrictus adults in winter rape was 5.8-25.8 times higher compared with spring rape. High abundance of weevils in winter rape was recorded at GS 65-73. Oviposition lasted for 2-3 weeks in winter rape and 1-2 weeks in spring rape. Infestation of larvae lasted for 6-7 weeks in winter rape pods and 2-4 weeks in spring rape pods.

5. C. obstrictus larvae damaged $5-7 \%$ of winter rape and $4-5 \%$ of spring rape pods; however, the damage in both crops was less yield-limiting. The abundance of C. obstrictus larvae/pod highly and significantly correlated with the percentage of damaged pods.

\section{Acknowledgements}

The paper presents research findings, obtained through the long-term research programme "Harmful organisms in agro and forest ecosystems" implemented by Lithuanian Research Centre for Agriculture and Forestry. Authors thank Dr. Vytautas Tamutis for helping with identification of Ceutorhynchus species.

Received 02072012 Accepted 19082013

\section{References}

Alford D. V., Nilsson C., Ulber B. 2003. Insect pests of oilseed rape crops. Alford D. V. (ed.). Bio control of oilseed rape pests, p. 9-41

Bromand B. 1990. Diversities in oilseed rape growing in the Western Palearctic region. IOBC-WPRS Bulletin, 13 (4): 7-31

Clever A. G., Scarisbrick D. H. 2001. Practical statistics and experimental design for plant and crop science

Dechert G., Ulber B. 2004. Interactions between the stem-mining weevils Ceutorhynchus napi Gyll. and Ceutorhynchus pallidactylus (Marsh) (Coleoptera: Curculionidae) in oilseed rape. Agricultural and Forest Entomology, 6: 193198 http://dx.doi.org/10.1111/j.1461-9555.2004.00220.x 
Dosdall L. M., Moisey D., Carcamo H., Dunn R. 2001. Cabbage seedpod weevil factssheet. Alberta Agriculture, Food and Rural Development Agdex

Ferguson A. W., Klukowski Z., Walczak B., Perry J. N., Mugglestone M. A., Clark S. J., Williams I. H. 2000. The spatio-temporal distribution of adult Ceutorhynchus assimilis in a crop of winter oilseed rape in relation to the distribution of their larvae and that of the parasitoid Trichomalus perfectus. Entomologia Experimentalis et Applicata, 95: 161-171

http://dx.doi.org/10.1046/j.1570-7458.2000.00654.x

Free J. B., Williams I. H. 1979. The infestation of crops of oilseed rape (Brassica napus L.) by insects. Journal of Agricultural Science, 93: 203-218 http://dx.doi.org/10.1017/S0021859600060652

Grantina I. Apenite I., Turka I. 2011 (a). Identification and control of rape stem weevil Ceutorhynchus spp. in winter oilseed rape in Latvia. International scientific conference Research for Rural Development. Jelgava, Latvia, 1: $13-17$

Grantina I., Apenite I., Turka I. 2011 (b). Commonly found species of Ceutorhynchus (Coleoptera: Curculionidae) on the oilseed rape in Latvia. Acta Biologica Universitatis Daugavpiliensis: 11 (2): 260-264

Hiiesaar K., Metspalu L., Laeaeniste P., Jogar K., Kuusi A., Joudu J. 2003. Insect pests on winter oilseed rape studied by different catching methods. Agronomy Research, $1(1): 17-29$

Kuhlmann U., Mason P. G. 2002. Use of field host range surveys for selecting candidate non-target species for physiological host specificity testing of entomophagous biological control agents. $1^{\text {st }}$ International Symposium on Biological Control of Arthropods. Hawaii, USA, p. 370-377

Kuhlmann U., Mason P. G., Hinz H. L., Blossey B., De ClerckFloate R.A., Dosdall L. M., McCaffrey J.P., Schwarzlaender M., Olfert O., Brodeur J., Gassmann A., McClay A. S., Wiedenmann R. N. 2006. Avoiding conflicts between insect and weed biological control: selection of non-target species to assess host specificity of cabbage seedpod weevil parasitoids. Journal of Applied Entomology, 130: 129-141 http://dx.doi.org/10.1111/j.1439-0418.2006.01040.x

Lancashire P. D. Bleiholder H., van den Boom T., Langeluddeke P., Stauss R., Weber E., Witzenberger A. 1991. A uniform decimal code for growth stages of crops and weeds. Annals Applied Biology, 119: 561-601 http://dx.doi.org/10.1111/j.1744-7348.1991.tb04895.x

Landschreiber M. 2005. Die Vorblütenschädlinge sind weiter auf dem Vormarsch. Raps, 23: 4-9 (in German)

Marczali Z. S., Keszthelyi M., Nadasy M., Budai P., Lehoczky E. 2010. Study on weevil pests of oilseed rape at Keszthely, Hungary. Communication Applied Biological Science, 75 (3): $323-328$

Moser D., Drapela T., Zaller J., Frank T. 2009. Interacting effects of wind direction and resource distribution on insect pest densities. Basic and Applied Ecology, 10: 208-215 http://dx.doi.org/10.1016/j.baae.2008.03.008

Murchei A. K., Williams I. H., Alford D. V. 1997. Effects of commercial insecticides treatments to winter oilseed rape on parasitism of Ceutorhynchus assimilis Paykull (Coleoptera: Curculionidae) by Trichomalus perfectus (Walker) (Hymenoptera: Pteromalidae). Crop Protection, 16: 199-202 http://dx.doi.org/10.1016/S0261-2194(96)00103-2

Sedivy J., Vasak J. 2002. Differences in flight activity of pests in winter and spring oilseed rape. Plant Protection Science, 38 (4): $139-144$
Smreczynski S. 1972. Klucze do oznaczania owadów. Polski, Cz. III (98d): Chrząszcze - Coleoptera: Ryjkowce Curculionidae, Podrodzina: Curculionidae (in Polish)

Tamutis V. 2002. Influence of some ecological factors to abundance of seed pod weevil (Ceutorhynchus asimmilis Payk.) in winter oil seed rape commercial plots. Baltic Journal of Coleopterology, 2 (1): 83-88

Tamutis V., Tamute B., Ferenca R. 2011. A catalogue of Lithuanian beetles (Insecta, Coleoptera). ZooKeys 121: 1-494 http://dx.doi.org/10.3897/zookeys.121.732

Tarang T., Veromann E., Luik A., Williams I. 2004. On the target entomofauna of an organic winter rape fields in Estonia. Latvijas Entomologs, 41: 100-110

Toshova T., Subchev M., Toth M. 2009. The diversity of species of Ceuthorhynchinae captured in traps in the region of Sofia, Bulgaria. Bulletin of Insectology, 62 (1): 27-33

Ulmer B. J., Dosdall L. M. 2006. Spring emergence biology of the cabbage seed pod weevil (Coleoptera: Curculionidae). Annals of the entomological society of America, 99: 64-69 http://dx.doi.org/10.1603/00138746(2006)099[0064:SEBOTC]2.0.CO;2

Williams I. H. 2010. The major insect pests of oilseed rape in Europe and their management: an overview. Horowitz A. R., Ishaaya I. (eds). Insect pest management, p. 1-45

Williams I. H., Free J. B. 1979. Competition of oilseed rape (Brassica napus L.) plants after damages to their buds and pods. Journal Agronomy Science, 92: 53-59

Williams I. H., Buchs W., Hokkanen H., Menzler-Hokkanen I., Johnen A., Klukowski Z., Luik A., Nilsson C., Ulber B. 2003. Management strategies for winter oilseed rape pests to enhance bio-control of rape pests. $11^{\text {th }}$ International Rapeseed Congress. Copenhagen, Denmark, p. 1011-1013 
ISSN 1392-3196 / e-ISSN 2335-8947

Zemdirbyste-Agriculture, vol. 100, No. 3 (2013), p. 293-302

DOI 10.13080/z-a.2013.100.038

\title{
Paslėptastraublių (Ceutorhynchus spp.) rūšių ịvairovė, migracijos aktyvumas ir žalingumas žieminiuose bei vasariniuose rapsuose
}

\author{
B. Vaitelytė, I. Brazauskienè, E. Petraitienè
}

Lietuvos agrarinių ir miškų mokslų centro Žemdirbystès institutas

\begin{abstract}
Santrauka
Ceutorhynchus rūšiu ịvairovès ir jų migracijos aktyvumo tyrimai atlikti 2010-2012 m. Lietuvos agrarinių ir mišku mokslų centro Žemdirbystès institute. Geltonosios vandens gaudyklès buvo naudojamos Ceutorhynchus rūšiu vabalams rinkti, o šių vabalų kiaušinėlių ir lervų vystymasis įvertintas ant lapkočių, stiebų ir ankštarų žieminių bei vasarinių rapsų pasėliuose. Paslèptastraubliu (Ceutorhynchus spp.) gausumas buvo gerokai didesnis žieminiuose rapsuose, lyginant su vasariniais. Žieminiuose bei vasarinuose rapsuose dominavo trys paslèptastraublių rūšys: Ceutorhynchus pallidactylus, C. typhae ir C. obstrictus. C. pallidactylus skraidymo aktyvumas žieminiuose rapsuose kasmet prasidejo BBCH 39 tarpsniu ir tęsèsi 4-5 savaites, o vasariniuose rapsuose - BBCH 9 ir truko tik 1-2 savaites. C. pallidactylus kiaušinèlių dètis abiejuose augaluose truko 2-4 savaites. Daugiausia C. pallidactylus lervų žieminiuose rapsuose nustatyta BBCH 65-67 tarpsniu, vasariniuose - BBCH 57-61 tarpsniu. Lervos abiejų augalų lapkočiuose ir stiebuose buvo aptinkamos 5-6 savaites. Didelis C. obstrictus suaugèlių gausumas žieminiuose rapsuose nustatytas augalams esant BBCH 65-73 tarpsnio, tačiau šio kenkèjo migracija ị vasarinius rapsus visais tyrimų metais buvo nedidelè. Žieminiuose rapsuose $C$. obstrictus kiaušinèlių dètis truko 2-3 savaites, o vasarinuose rapsuose - 1-2 savaites. Didžiausias kiekis $C$. obstrictus lervu žieminiuose rapsuose nustatytas $\mathrm{BBCH} 73-79$, vasarinuose - BBCH 67-75 tarpsniais. Stipri ir esminè koreliacija $\left(p=0.05^{*}, p=0.01^{* *}\right)$ nustatyta tarp C. pallidactylus lervų gausumo ir jų pažeistų stiebų kiekio $\left(r=0.909^{* *}\right)$, taip pat tarp C. pallidactylus lervų gausumo ir ju pažeisto stiebo ilgio $\left(r=0.931^{* *}\right)$. C. obstrictus lervu gausumas ankštarose taip pat stipriai ir esmingai koreliavo su pažeistų ankštarų bei sẻklų kiekiais (atitinkamai $r=0.874^{*}, r=0.931^{* *}$ ).
\end{abstract}

Reikšminiai žodžiai: Brassica napus, Ceutorhynchus obstrictus, Ceutorhynchus pallidactylus. 